\title{
The Role of Economic Agent and Traditional Institution on the Sustainability of Sasi Culture in Maluku, Indonesia
}

\author{
Faidah Azuz ${ }^{1}$, Aylee Christine Alamsyah Sheyoputri ${ }^{2}$ \\ Universitas Bosowa, Makassar, South Sulawesi, Indonesia
}

\begin{abstract}
This research is aimed to analyze the role of economic actors and traditional institutions to the survival of cultural system Sasi especially "Sasi Pala" ( nutmeg sasi) in Maluku Island. The study used a qualitative approach post structuralism perspective. Data obtained by in-depth interviews that involving 35 informant from Negeri Morella district at Central Maluku. Data analysis techniques were using interpretation techniques and triangulation. The results of this study indicate that Sasi traditional culture system developed in the Morella country not due to maintain awareness tradition but more on the needs of the economy after the decline the price of cloves due to business administration policy and the SARA conflict in Maluku. Nutmeg plants become the foundation of the economy which is managed by Sasi head ruler. Therefore Sasi is transformed from traditional system into modern system because of economic necessity of the community, the mechanisms role of the community that applied to the Sasi is no longer customary system but economic modern system. The mechanism through an auction to determine the ruler Sasi fellow one year with a frequency of three times the harvest. Economic actors will deposit the funds of the auction bid for the benefit of the mosque as tradition and further support custom leader as representatives of the community handed over control, withdrawal of excise crops with a ratio of 1:10, and the purchase of nutmeg wet as a monopoly. The Sasi nutmeg, which lasted from 2004 to 2015, have show the consistency of the application of the Sasi auction mechanism nutmeg. This study found that although Sasi is a Moluccan culture, but when the economy needs urgent, Sasi nutmeg in the realm of culture shifted into the economic sphere.
\end{abstract}

Keywords: Sasi, Nutmeg, Economic Actors, Traditional Institutions, Cultural Sustainability.

\section{Introduction}

Sasi for Moluccan culture traditional system is the form of management of the natural resources by taking into account the prohibition of taking certain natural products or resources, both at sea and on land for a certain period of time. In the context of zoning regulation, Sasi is divided into two zones, Sea Sasi or Marine Sasi is the regulation for community who possess the cultural system for taking ao harvesting marine products and land Sasi such as fish, sea cucumber and others marine products. Land Sasi is regulation for some types of plants which has been main products of the Malucan communities.

In terms phases, The Sasi sysrem has three phases namely; the open Sasi where community should take natural products by wisely used the area that will harvest, Secondly, the close Sasi when the community are prohibited of taking the natural resources), and lastly, the Sasi sanctions, where in case of violation of the community role in managing their natural resources. More over the society can only take the natural resources or harvest their natural resources, when there is a permission from the local custom leader.

The studies on culture system of Sasi, has been done in two approaches. The first approach is Sasi aspects of natural resource conservation, and other studies is related to the community culture or traditional community system that possesses by the Maluku community including how local culture survived the onslaught of globalization [1]-[5].

Various studies have been done about the Sasi traditional system, the relevant study of Sasi show that the application of the Sasi in the sea can increase the quality and quantity of production of marine products therefore it is increasing its economic value of the natural resources products. However, not all marine Sasi boils down to economic interests, the othe examples shows that the Sasi of lompa fish (Sasi ikan Lompa) more on the application of tradition ritual of the community rather than the community role in the protecting their environment or managing their traditional system in terms of economic value. This reality can be understood that the sea Sasi has two meanings that utilization and conservation of the environment as well as sustain the culture value of Maluku tradirional community [6][7].

Studies that have been done are almost all related to the sea Sasi. Whereas the people of Maluku largely dependent on their agricultural sector for examples the main plants such as; cloves and nutmeg. Historically and agronomically, the nutmeg and cloves in the Moluccas has formed a cultural construction in community management and supported by the natural suitability of the plants. For examples; Nutmeg plants become the foundation of the local economy of Maluku since the fall in prices due to the policy clove trading system in 1992-1997 [8]. The Nutmeg crop management through Sasi systems shows the crops has been occupy an important position in the economic lifely hood of the community and its culture that possesses by people of Maluku. On the other hand, the research which is specifically discuss about Sasi nutmeg crop system and how to examine the effect of economic actors and traditional institutions hasn't been exposed due to traditional systems is closed to the others system. Therefore there is a need to see sociological approaches can be put in perspective post strucrualism of the community who possesses the Sasu mechanism in protecting 


\section{International Journal of Science and Research (IJSR) \\ ISSN (Online): 2319-7064}

Index Copernicus Value (2015): 78.96 Impact Factor (2015): 6.391

their environment on the other ways to improve the community lifely hoods. Moreover, with a qualitative approach. At this level the position of studies on the role of economic actors and traditional institutions in Sasi nutmeg is described to become modern system.

\section{Research Methods}

The study was conducted by the method of poststructuralism perspective, the perspective of denying the relationship between variables liner or the elements and are in the realm of qualitative. The consideration is the social reality, including the reality of culture is not a single stand.

The qualitative methods are used to understand the mechanism of the traditional system which are possesses by the traditional community. It is also shows the traditional system can be survive in the modern system. The qualitative methods also reveal some issues related to the change on the traditional trading system and how the institutions are changing their role.

Studies in this sphere aimed at seeing changes in the application of which is expected to understand Sasi answers that are not binary opposition and linear. The study was conducted in the Morella District of Central Maluku, Maluku province that consistently has done and using Sasi nutmeg crop trading system. Data obtained through depth interviews with 35 informants consisting of economic actors and indigenous leaders. The analysis technique used is the interpretation and triangulation. The indicators used in this study is the role of traditional institutions, the role of economic actors, and nutmeg Sasi continuity from year 2004 to 2015 .

\section{Results and Discussion}

The origin of the State of Morella is an amalgamation of some Aman (Hena) or the Old Country, namely Old Country Kapahaha, Old Land Iyal Uli, Land of Old Putulesi and Negeri Nurnareta Old. Fourth Safe or Old Country is what forms a Safe or Affairs Hausihu Morella.

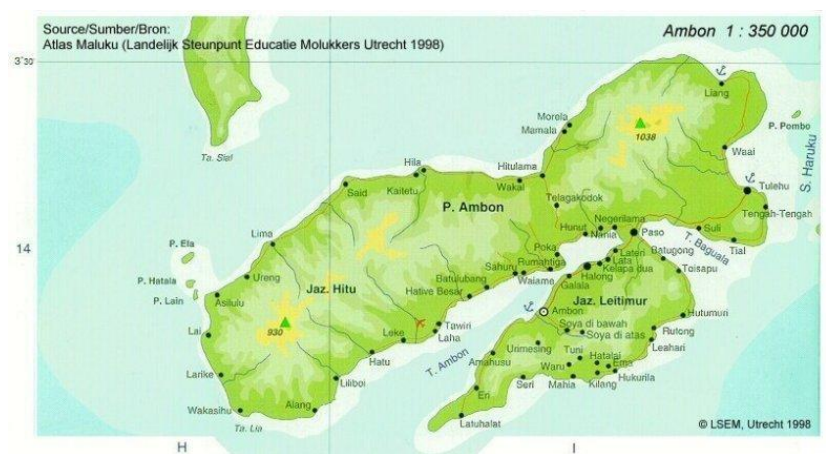

Figure 1: Map of the Province of Maluku

According to traditional elders, the ancestors who lived in the old countries came from Ula Pokol. Ula Pokol is the centre of the first country since the first, is also a place that is very sacred to the people of Morella because it is believed to be the habitation of the Invisible Spirit (Rijalal Gaib). Ula Pokol located in the mountains of Salahutu, the first living place is Uka Latu Tapil, He comes from the Middle East. Uka Latu Tapil came to the scene with a bird Manulatu (Bird King).

Also told by the Indigenous elders after Uka Latu Tapil was in Ula Pokol appeared three people who each claimed to be the predecessor or inventor of the new area, amid the fierce debate that suddenly they heard the chirp of Manulatu Bird. Eventually, they realised that the area was already inhabited and the three of them agreed to find the owner of Manulatu. The three men are Tuhe, Meten and Hiti. Not long afterwards Tuhe, Meten and Hiti found the man sought in Ula Pokol, while he was sitting meditating (Praying).

In front of the sitting person, they pledge "Upu Tapil Ame" which means our Lord Protector / Visitor; he is the Uka Latu Tapil. Tuhe, Meten and Hiti are then confirmed as Hulubalang or guardians of Uka Latu Tapil, then Uka Latu Tapil then put three stone in Salahutu as "Hatu Manuai Telu" or Batu Tiga Tuan Tanah (Land of Tuan) because this is where Tuhe, Meten and Hiti meet.

In the next development Tuhe Meten and Hiti proposed a daughter named Hatuatina from Nusa Ina (Pulau Seram) precisely at the center of three streams Eti, Tala and Sapalewa in Nunusaku Salahua to become the wife of $U k a$ Latu Tapil, from the marriage was Uka Latu Tapil and His wife obtained seven sons and one daughter. Of the seven boys is only a child named Tuharela who lead a normal life as a human, while the other six live as a Sufism Tulen (Unseen). Tuharella had a woman named Alungnusa from Seram Island. It is from this marriage that gave birth to the majority of Morella people now.

Through the process of marriage, more and more people in the place (Ula Pokol) and because of the natural conditions, they also make a move to some locations in the mountains to Ama Ela (Gunung Kukusan) then move back to Kapahaha and partly to Iyal Uli, Ninggareta, and Putulessy. Although the four old countries separated from one another, their lives are united in the social life system, where the centre of adat is in Kapahaha, then the highest adat leader in Tuhe, Meten, and Hiti (Salamoni). The religious implementation focused in Iyal Uli.

From the century to the life of these four old countries in a state of peace and harmony, until the end of the 6th century when the Occupying Nation entrenched in Maluku, these four ancient lands united to defend their territory from invaders' attacks. Kapahaha then serves as a centre of defence against the colonists this is because of its strategic location with Kapitan Telukabessy (Ahmad Leikawa) as the warlord. At that time some of the fortresses in Maluku had been conquered by the Dutch so that the capitals and males from these areas added with reinforcements from other sectors joined in Kapahaha Fort like the Kingdom of Ternate, Kingdom of Gowa, Tuban, Alaka, Huamual , Iha, Buru, Nusa Laut, Banda and others. They fought against the Company that lasted from 1637 to 1646 .

When in 1646 Kapahaha was conquered by the Dutch colonialists, all the people of Kapahaha, the Kapitan and

\section{Volume 6 Issue 7, July 2017}




\section{International Journal of Science and Research (IJSR) \\ ISSN (Online): 2319-7064}

Index Copernicus Value (2015): 78.96 | Impact Factor (2015): 6.391

malesi and all the aid personnel were descended from the Kapahaha Landscape and held captive at Teluk Telapuan Bay (Teluk Sawatelu Morella).

After the announcement of the release of prisoner of captive war by governor Van Deimer, they held a farewell ceremony before returning to their respective areas, in the farewell ceremony filled with traditional songs and dances as well as a group of Kapahaha Youth performing the Beat Swords of Lidi. That day, which coincided with the date of October 27, 1646 , they gave the name of the People of Kapahaha which they will leave with the title of Hausihu which means Fire Flame of Struggle (Kapahaha Hausihu Holi Siwalima).

Meanwhile, the people of Kapahaha Hausihu by the Dutch were not entrusted to return to the Old Country in the mountains too (or "intending to") facilitating Dutch control of them. So they then occupy the region approximately $3 \mathrm{~km}$ towards the south of the Sawatelu Morella region now with the name of his country Hausihu Morella.

Hausihu Morella country belongs to the Ulisailessy region along with Liang and Waai Affairs. Particularly for hausihu Morella country, there are some small dati such as:

- Huta Haha as dati Tuhe

- Ima Uli dati as Manilet

- Sia' Aman as dati Sialana

- Uli Kau as dati tawainlatu

- Uli Ina as dati Leikawa

- Ninggareta as dati Ulath

- Putulessy as dati Latukau

- Sipil as Lekai

- Ula Pokol as dati Sasole

\subsection{Traditional institution}

Village cooperatives are organisations in rural areas that are engaged in providing community needs related to agricultural activities [1]. Village groups can also be said to be a platform for an economic organisation with a social character and is a venue for the development of various economic activities of rural communities organised by the community and for the community itself [2]. Village cooperatives can also be referred to as all-around cooperatives as they seek to meet various fields such as savings and loans, consumption, production, marketing and services [3].

The village unit cooperative is expected to become a pillar of the economy and able to play an active role in expanding the small-scale economy and family businesses in the community by helping to channel production facilities and marketing agricultural products. Other than that the city unit cooperative is also expected to provide technical guidance to farmers who still use traditional technology that is by conducting counselling and courses for farmers. Guidance and advice for farmers are needed because to increase the production of the results of perdananian. Given this it is expected that the ultimate goal is to improve the welfare of farmers in rural areas [4]
This study also able to show the amount of nutmeg Sasi auction results for eleven years. Amount of the highest bid is presented in Table 1.

Table 1. Sasi Authorization Holder and Amount of Auction Nutmeg Sasi Year 2005-2015 in Morella

\begin{tabular}{|c|c|c|c|}
\hline Years & Authorization Holder & Offers & $\begin{array}{c}\text { Amount of } \\
\text { Auction }\end{array}$ \\
\hline 2005 & KUD Tomasiwa & 15.000 .000 & 17.000 .000 \\
\hline 2006 & A & 17.000 .000 & 20.000 .000 \\
\hline 2007 & A collaboration with KUD & 18.000 .000 & 20.000 .000 \\
\hline 2008 & KUD Tomasiwa & 20.000 .000 & 22.500 .000 \\
\hline 2009 & B collaboration with KUD & 22.500 .000 & 25.000 .000 \\
\hline 2010 & B & 25.000 .000 & 27.000 .000 \\
\hline 2011 & C & 27.000 .000 & 30.000 .000 \\
\hline 2012 & D & 35.000 .000 & 41.000 .000 \\
\hline 2013 & D & 35.000 .000 & 41.000 .000 \\
\hline 2014 & D & & 41.000 .000 \\
\hline 2015 & D & & 40.000 .000 \\
\hline
\end{tabular}

Based on the above table, in the period 2005 Sasi discontinued after the first harvest because of crops inadequate. Community cooperation institutions auction withdraw funds that had been deposited into the mosque by 50 percent. In the period of 2012 , harvesting only twice, at the start and end of the year. Harvesting middle or intermediate harvest was canceled due to season erratic so nutmeg production was not optimal.

Shown in Table 1 that nature the last four years there is only one economic actor who holds the power of Sasi. This situation generally does not cause problems for the continuity of nutmeg Sasi. However, if explored further, the possibility of accumulation of capital on the one hand will occur.

Negeri Morella is tradition land used as a guide behaved particularly in the realm of culture. Generally, the Moluccas lay within the realm of their traditional Sasi. This is in contrast to the opinion of Morella. Although they are in indigenous communities, but Sasi is not tradition. Morella understand that the tradition people are the rules of behavior that took place in Negeri Lama that had been abandoned when losing the war against the VOC in 1646. Morella community found Sasi is not tradition because of newly implemented in the year 1968 to 1972 to obtain funds for mosque repairs.

Communities then construct a mosque affairs as tradition affairs because of the mosque has been since I was in Negeri Lama (in the mountains). Sasi position nutmeg are tools to support the needs tradition (mosque). There is a consensus that a local businessman who plays as a prince of the mosque will lend mosque construction. Refunds will be made after the harvest nutmeg. This is the beginning of the community Morella conduct nutmeg Sasi. Employers who lend funds (power holders of nutmeg Sasi) that determines when to open and close the Sasi and what the sanctions for breach of Sasi. At the time of opening the Sasi (a harvesting) the community must submit nutmeg with a ratio of 1:10 to entrepreneurs are referred to as excise duty. Accumulation excise duty is then considered as a refund of loans from local businessmen. Nutmeg crop can be harvested three times a year, which 


\section{International Journal of Science and Research (IJSR) \\ ISSN (Online): 2319-7064}

Index Copernicus Value (2015): 78.96 | Impact Factor (2015): 6.391

means the holder of the power of Sasi obtain excise duty nutmeg three times in a period of the loan.

Sasi nutmeg in Morella can not be implemented without the approval tradition institutions, because of Sasi intended for the management of funds for the mosque located in indigenous territories. Thus the role of traditional institutions against Sasi nutmeg as legitimator.

\subsection{Economic agents}

In 1972, Sasi is stopped and held back after the community experienced two important events Morella. First, the declining price of cloves as a result of enforcement of the clove trade system policy years 1992-1998. Second, as a result conflict in Maluku of the 1999-2004 where hundreds of people lost their jobs. Nutmeg later became the foundation of the household economy Morella the community. Sasi nutmeg performed again, still with the goal of the interests of operational funds mosques and to obtain optimal of plants yield.

Among fellow economic actors (the capital) who lived in Morella then make a consensus to limit the auction participants nutmeg Sasi. Which means that only the people of Morella is allowed to participate in the auction nutmeg Sasi. This implies two things. First, the potential of nutmeg actually utilized for the empowerment of local communities. Second, at the same time, in fact economic actors limit the emergence of other competitors from outside of Morella. This restriction as well as a strategy to confront the economic agents for eleven years (2004-2015). According to Bourdieu, restrictions on economic actors from outside is a way to reproduce the culture for the sake of strengthening habitus [9].

\subsection{Sustainability of Nutmeg Sasi}

Nutmeg Sasi conducted through auction redress mechanisms proven to work for eleven years without stopping. If in Morella understood as the local culture, the presence of economic actors and traditional institutions can not be denied. They have role of each to make efforts so that Sasi is still being done in Morella until today.

For the data above it shows there is a advantage in using the Sasi Pala as the mechanism of trading system the data shows that there is a differences between the amount of auction and the prices, therefore the traditional system aslso can improve the community prospherity in terms of added value of the harvesting.

\section{Conclusion}

This study resulted in several conclusions which acts as a customs agency Sasi legitimator nutmeg, while the economic actors take on the role as executor Sasi nutmeg. Sasi nutmeg for Morella is not tradition, but ordinary culture. Sasi position only as a tool to support the implementation of the tradition (mosque). Through collaborations like this Sasi nutmeg can take place continuously for eleven years in
Morella.

\section{References}

[1] J. T. Collins, "Language death in Maluku The impact of the VOC," Bijdr. tot Taal-, Land-en Volkenkd., vol. 159, no. 2/3, pp. 247-289, 2003.

[2] V. Valeri, The forest of taboos: Morality, hunting, and identity among the Huaulu of the Moluccas. Univ of Wisconsin Press, 2000.

[3] M. E. Gallagher, Contagious capitalism: Globalization and the politics of labor in China. Princeton University Press, 2011.

[4] M. Lock and V.-K. Nguyen, An anthropology of biomedicine. John Wiley \& Sons, 2010.

[5] C. K. Ikwuemesi, "Art as a tool for cross-cultural conversation: A personal dialogue with Igbo and Ainu art," Cogent Arts Humanit., vol. 3, no. 1, p. 1262997 , 2016.

[6] A. Satria and D. S. Adhuri, "Pre-existing fisheries management systems in Indonesia, focusing on Lombok and Maluku," in Managing Coastal and Inland Waters, Springer, 2010, pp. 31-55.

[7] D. S. Adhuri, Selling the Sea: A study of conflict over marine tenure in Kei Islands, Eastern Indonesia. ANU Press, 2013.

[8] M. Habibi, "Peran Tokoh Masyarakat Sebagai Aktor Penerus Warisan Budaya Di Tanah Perantauan (Studi: Sanggar Budaya Kuda Lumping Campur Sari Turonggo Sri Margo Mulyo Desa Bhuana Jaya, Kecamatan Tenggarong Seberang Kabupaten Kutai Kartanegara)," FISIPublik, vol. 1, no. 1, 2016.

[9] P. Bourdieu, "A dominação masculina," in A dominação masculina, Bertrand Brasil, 2010. 